\title{
Schelling's Aesthetic Turn in the System of Transcendental Idealism
}

\section{Michael Stephen G. Aurelio}

\begin{abstract}
This paper inquires into what the philosopher F.W.J. Schelling saw was the fundamental relationship between art and philosophy. Widely regarded only as a transitional thinker between Fichte and Hegel in the development of transcendental idealism, Schelling in his System of Transcendental Idealism (1800) develops the rather novel insight that transcendental philosophy finds its full expression in the philosophy of art. Taking into account the nature and the limits of both "transcendental philosophy," which begins with the thought and consciousness of the I, and also of "natural philosophy" or science, which begins with the sensible and the non-conscious world, Schelling saw that it would be the responsibility of art to synthesize and unite the two opposing branches of philosophy. After describing the "artistic genius" and determining the nature of the work of art toward the last part of the System, Schelling boldly claims that in his creations the artist is able to resolve the contradiction between the ideal and the real, between the I and the world. Well before Hegel, Schelling thus foresaw that science and philosophy are destined to return to poetry and art in the course of history.
\end{abstract}

Keywords: Schelling, transcendental idealism, aesthetics, art

Art was a union of the father and the mother worlds, of mind and blood. It might start in utter sensuality and lead to total abstraction; then again it might originate in pure concept and end in bleeding flesh.

- Hermann Hesse ${ }^{1}$

$\mathrm{F}$ riedrich Wilhelm Joseph von Schelling (1775-1854) in the beginning of his turn of the nineteenth century work System of Transcendental Idealism (1800) dogmatically stated that "All knowledge is founded upon the coincidence of an objective with a subjective." ${ }^{2}$ This characteristic watchword and

${ }^{1}$ Hermann Hesse, Narcissus and Goldmund, trans. by Ursule Molinaro (New York: Picador, 2003), 171.

(C) 2012 Michael Stephen G. Aurelio http://www.kritike.org/journal/issue 11/aurelio june2012.pdf ISSN 1908-7330 
battle cry of German Idealism, which implies that true knowledge is nothing else but the identity of the subject with the object, or the I and the not-I as Fichte put it, is, however, not wholly original. Aristotle already hinted at the uniformity between knower and known when he said in his De Anima that "Actual knowledge is identical with its object." The Philosopher, who was always careful and rigid in his writings, would later on curiously remark, as if hesitantly, in the same work that perhaps "the soul is in a way all existing things."

But where Aristotle was prudent and conservative, Schelling was firm and confident. Influenced more by Plato ${ }^{4}$ whom he avidly read in Greek in his youth, there is, according to Schelling, not only a direct correspondence or an unmistakable similarity between the self and the world, between the ideal and the real, in the occasion of knowledge. For the thinker who paved the way for Hegel's absolute idealism, knowledge is nothing less than the absolute identity between the subject and the object, where the ideal is the real, and the self is the world.

Schelling saw that any attempt to clearly determine such an absolute identity was at bottom the attempt to answer the question Kant had earlier posed: "How can we think both of presentations as conforming to objects and objects as conforming to presentations?" Schelling, who delighted in uniting contradictions, saw that resolving the opposition between the subject and the object-one which for his part Kant solved by giving primacy to the subject to whom objects conformed-was according to him "not the first, but the highest task of transcendental philosophy." ${ }^{\prime}$

The idealist aim of achieving absolute identity between knower and known nevertheless presupposes and requires much. First, Schelling supposes that there must be a meeting point between the two mutually opposed worlds, a kind of horizon which touches both realms. Secondly, Schelling at the same time underscores that in any possible identity, the opposition between the antagonists must not destroy the reality of one another by, for example, dissolving the other into itself, thus forming a homogenous identity. In one enigmatic passage he says that while the subject and the object do "cancel each other out," it must still be held

${ }^{2}$ F.W.J. Schelling, System of Transcendental Idealism (1800), trans. by Peter Heath and with an introduction by Michael Vater (1978; repr., Charlottesville: University Press of Virginia, 2001). Page citations are to the reprint edition.

${ }^{3}$ Emphasis mine. In full, Aristotle says: "Actual knowledge is identical with its object"; and "the soul is in a way all existing things; for existing things are either sensible or thinkable, and knowledge is in a way what is knowable, and sensation is in a way what is sensible: in what way we must inquire." See Aristotle, De Anima 3.7.431a1 and 3.8.431b20-23, respectively.

${ }^{4}$ For more on the early influences on Schelling's thought, see Frederick C. Beiser, The Romantic Imperative: The Concept of Early German Romanticism (Cambridge: Harvard University Press, 2003), 71.

${ }^{5}$ As Schelling phrased it. See Schelling, System, 11.

${ }^{6}$ Ibid. 
that "neither is possible without the other." "The subject," he elaborates further, "asserts itself only in opposition to the object, and the object only in opposition to the subject; neither, that is, can become real without destroying the other, but the point of destruction of one by the other can never be reached, precisely because each is what it is only in opposition to the other."

Without either acceding to the eventual dissolution of the necessary difference and relaxing the mutual tension between the subject and the object, Schelling's next move would be a peculiar one: instead of looking for similarities between the ideal and the real where they can possibly meet, Schelling proposes that between the two there is what he will call a "predetermined harmony." Echoing Leibniz, whose Monadology he also read even before his formal philosophical studies, ${ }^{8}$ Schelling thinks that there must exist a kind of tension which paradoxically unites rather than separates, a kind of discord that, to wit, gathers different notes to form one melody, or a kind of intimacy that could, for example, secure two absolutely different persons in love instead of dividing them in hate. This paradoxical predetermined harmony between two destructive elements, to be sure, is not the gift of a god, or an arbitrary metaphysical postulate. For Schelling, any such unity between the ideal and the real is to be produced and accomplished by the very activity of self-consciousness, or the I itself. In full, Schelling says that

how both the objective world accommodates to presentations in us, and presentations in us to the objective world, is unintelligible unless between the two worlds, the ideal and the real, there exists a predetermined harmony. But this latter is itself unthinkable unless the activity [of the subject], whereby the objective world is produced, is at bottom identical with that which expresses itself in volition, and vice versa. ${ }^{9}$

How is Schelling to be understood here? What does he mean when he says that the objective world is produced? In a somewhat vague proposal, Schelling here argues that any harmony between the subject and object is possible only if the objective world could be traced back to the subject, as its very source and achievement. In what without a doubt echoes his master, Schelling here agrees with Fichte that like the I itself, the non-I, or the objective world, is a posit of active self-consciousness (Tathandlung). Where he does seem to part ways with

\footnotetext{
${ }^{7}$ Ibid., 46.

${ }^{8}$ Martin Heidegger, Schelling's Treatise on the Essence of Human Freedom, trans. by Joan Stambaugh (Athens, Ohio: Ohio University Press, 1985), 4.

${ }^{9}$ Schelling, System, 11-12.

(c) 2012 Michael Stephen G. Aurelio http://www.kritike.org/journal/issue_11/aurelio june2012.pdf ISSN 1908-7330 
Fichte is his supposition that while the objective world was originally an accomplishment of the I, that it was indeed so is something that the I has become unconscious of: that is, the apparently distinct world is primordially the very same I which only forgot itself. The goal then in rendering the unity between the I and the non-I, in turn showing the harmony between the self and the world, is to awaken the hitherto dormant world to the light of self-consciousness, and to remind the hitherto oblivious I what it only has forgotten - that it was the world all along. At bottom, absolute identity between the self and the world is to be achieved only if the self can, as in a second creation, refashion the world and express it anew-but this time consciously, and by its own freedom and will.

Curiously, the gradual revelation that the subject is after all the object will neither be the transcendental philosopher's task, as he can only limit his inquiries to self-consciousness guided by intellectual intuition; nor will it be the natural philosopher's business, as he is prohibited to enter the realm of the self, having to stay within the limited horizon of sensible intuition. On the one hand, transcendental or theoretical philosophy, the tradition that he inherits from Fichte before him (but can be traced back to Kant), and what will also find full expression in Hegel after him, will only be able to inaugurate the problem of the possibility of an absolute identity but will not be able to respond to it primarily because consciousness is separate from the world and only organizes its objects. On the other hand, neither natural philosophy nor the sciences can be sufficient in uniting the world and consciousness primarily because they need transcendental philosophy to breathe into the brute existence of nature a "soul" through thought or reflection, which is the very task and high claim of the transcendental philosopher. If transcendental philosophy is the movement from intelligence to nature, and if natural philosophy is the movement from nature to intelligence, both would thus be necessary in completing a system where self-consciousness and the world can mirror themselves in each other and finally be identical: the ideal becomes the real, the real becomes the ideal. As Schelling summarizes in his programmatic introduction: "Just as natural science brings forth idealism out of realism, in that it spiritualizes natural laws into laws of mind, or appends the formal to the material, so transcendental philosophy brings forth realism out of idealism, in that it materializes the laws of mind into laws of nature, or annexes the material to the formal." ${ }^{10}$

The only problem is that in order to accomplish the spiritualization of realism and the materialization of idealism at the same time, a third philosophy would thus be necessary whose task would be to resolve the opposing movements of the two philosophies, making sure that they meet. In a remarkable move by which he distances himself from Fichte, Schelling foresaw that the responsibility of making the self and the world reflect each other fell solely in the hands of not

${ }^{10}$ Ibid., 14.

(C) 2012 Michael Stephen G. Aurelio http://www.kritike.org/journal/issue 11/aurelio june2012.pdf ISSN 1908-7330 
another philosopher, but of the majestic artist—who, in an aesthetic intuition, gives expression to the world and grants appearance to the mind. It is in works of art, in which both imagination and reality at once clash and attain harmony, where any possible absolute identity between the self and the world can be made manifest. Thus the surprising aesthetic turn Schelling takes toward the end of the System of Transcendental Idealism.

Anticipating this conclusion, Schelling in the introduction already declares that "The objective world is simply the original, as yet unconscious, poetry of the spirit; the universal organon of philosophy—and the keystone of its entire arch—is the philosophy of art. ${ }^{11}$

\section{The Artist and the Nature of the Work of Art}

Such a reconciliation of the no less absolute opposition between the self and the world is possible only because according to Schelling the absolute can itself be concretely found in the very person and life of a "genius," a title, to note, that he reserves only for great artists. ${ }^{12}$ Schelling finds no difficulty in locating in the artistic genius the abode of the absolute. It is after all plain for Schelling that no other being is predisposed or falls prey more easily to contradiction, paradox, and conflict than the artist. Unlike the scientist who does not go beyond what is evident, or the logical philosopher who is afraid of contradictions, the artist not only thrives in opposition, but is himself a living contradiction.

One contradiction that can be found in the artist is his ability to paint what he nowise saw nor could possibly see, to say what he does not fully understand or mean, or create what he could never have imagined himself capable of creating. Some of us are familiar with those uncanny instances when, after writing a poem or drawing a landscape, or even something as simple as taking a photograph, we sometimes are beside ourselves in disbelief that it was us who while no poet wrote that perfect couplet, that is was $u s$ who while no painter disclosed the faint sorrow of the hills, and that it was us who while no professional

${ }^{11}$ Ibid., 12.

${ }^{12}$ Ibid., 222. Kant already in his Critique of Judgment described the attributes of the "genius," saying that genius is "the talent (or natural gift) which gives rule to Art" (\$46). Kant extols the genius as the recipient of a gift from nature that, because it is at every instance originary in the each artist, cannot be related to others or be taught. "Artistic skill," he says, "cannot be communicated; it is imparted to every artist immediately by the hand of nature; and so it dies with him, until nature endows another in the same way...” (\$47). The artist for Kant is therefore charged with the sole responsibility for the production of beauty by representing nature through the mutual use of his powers of imagination and understanding (\$49). In perhaps a similiar fashion, Schelling henceforth describes in a more dramatic and existential manner how the genius assumes such a fortunate (and at times unfortunate) responsibility. See Immanuel Kant, The Critique of Judgment, trans. by J. H. Bernard and with an introduction by Marc Luht (New York: Barnes and Noble Books, 2005), \$43-49, 105-121.

(C) 2012 Michael Stephen G. Aurelio http://www.kritike.org/journal/issue 11/aurelio june2012.pdf ISSN 1908-7330 
caught in our photographs what everyone else could have missed. Such a contradiction, while felt and experienced rarely by most of us, as though accidentally, is for the artistic genius his very being and essence-at once a blessing and a curse, at once providential and punishing. Thus we have the mad genius, or the tortured artist. Thus the gift of a van Gogh, a Beethoven, or a Hölderlin.

There is in each great artist, according to Schelling, a "dark unknown force," a spirit, as it were, which inspires him (in-spirare: to be inflamed, to be possessed by a spirit) to create what he otherwise could not perhaps create alone. And where else can that spirit come from other than from the commonly restrained world which calls on all creators? It is through the hands of the artist that the world is able to speak and finally reveal what it has not yet given appearance. What we call having an 'artistic eye' perhaps does not come from the artist possessing a certain privilege or 'talent' by birth or by right; the artist sees because the world offers itself to his vision in a way that it does not do so for the non-artist. The world attracts artists by calling on them; it seduces artists by at once showing and then hiding itself to and from them, speaking and then returning to its silence. A mystery to him, both seen and unseen, heard and unspoken, the world assigns to the artist the task of re-creating it and making it appear or speak-now in its full glory. Through that secret "power" bestowed upon him by the world, the genius is granted a kind of "destiny" which enables him to realize in his works "without [his] knowledge and even against [his] will, goals that [he] did not envisage."13

It sometimes happens though that the purpose of artistic creation is nothing metaphysical, mystical, or benevolent. Some artists create for selfish ends: they only wish to relieve themselves from the conflict between their consciousness and unconsciousness, minds and souls, to reconcile the voices within and without, and arrest the fleeting visions which from nowhere flash before their eyes. They may write or create in order to free themselves from the "dark unknown force" which hounds them. "It is the testimony of all artists," Schelling claims, "that they are involuntarily driven to create their works, and that in producing them they merely satisfy an irresistible urge of their own nature." ${ }^{14}$ Thus another paradox to be found in artistic creation is that it may not be a free activity at all (whereas everyone hears of that seldom understood "right of freedom of expression," one which is claimed as if exclusively by supposed artists). It is possible then that artists do not create freely but involuntarily, that is, by sheer necessity.

But by involuntarily setting down in a work of art what previously possessed him to no end, the artist also freely grants us a vision of the world no man can ever replicate. And the stronger the violence and tension inside the artist,

\footnotetext{
${ }^{13}$ Schelling, System, 12

${ }^{14}$ Ibid.
}

(C) 2012 Michael Stephen G. Aurelio http://www.kritike.org/journal/issue 11/aurelio june2012.pdf ISSN 1908-7330 
the more he is terrorized by the world, the more striking also his work of art appears to us. "No tears in the writer, no tears in the reader. No surprise in the writer, no surprise in the reader" (Frost). ${ }^{15}$ Yet to be sure, neither is the tension in the artist suddenly arrested or neutralized in the work of art, nor does it happen that the intensity of the artist is amplified in such a way that the work itself appears violent to us. On the contrary, an eerie calm, at once resounding and entrancing, resonates in a great work of art. Great works of art possess the qualities of intensity and silence in equal measure; in them opposition and tension are sustained in constant equilibrium-as if in indifference. We best see both stillness and violence, for example, in painting in a Caravaggio (The Martyrdom of St. Matthew, The Kiss of Judas, The Sacrifice of Isaac among others) or a Solomon (Samson).

But the power that great works of art display is only possible if the artist before the moment of creation already bore and absorbed within him the opposing forces of the self and the world. In creating his work he thus as it were 'merely' sets and freezes the opposition and tension into a lucid harmony which we in turn are able to experience ourselves. Upon the accomplishment of his work, the artist is finally able to deliver himself from the infinite opposition to which he had succumbed, enabling him to at last experience that long-awaited peace. Like the creator on the seventh day, Schelling speaks of a unique kind of tranquility the artist, as well as his creation, enjoy upon the completion of aesthetic production:

Every aesthetic production proceeds from the feeling of an infinite contradiction, and hence also the feeling which accompanies completion of the art-product must be one of infinite tranquility; and this latter, in turn, must also pass over into the work of art itself. Hence the outward expression of the work of art is one of calm, and silent grandeur, even where the aim is to give expression to the utmost intensity of pain or joy. ${ }^{16}$

And the "infinite tranquility" congealed and held in a visible work of art, able to capture and retain our restless gaze; or the predetermined harmony which is both set down and set free in a piece of art, able to speak to us personally in its mute silence; or that ineffable "holiness and purity" ${ }^{17}$ that illuminates all great works of art—gathered together, all these are just different descriptions of what we all recognize as beautiful. Beauty is nothing other than "the infinite finitely

${ }^{15}$ Robert Frost, preface to Selected Poems, with an introduction by Robert Graves (New York: Holt, Rinehart \& Winston, 1963), 2-3.

${ }^{16}$ Schelling, System, 225.

${ }^{17}$ Ibid., 227.

(c) 2012 Michael Stephen G. Aurelio http://www.kritike.org/journal/issue 11/aurelio june2012.pdf ISSN 1908-7330 
displayed." "The basic feature of every work of art," Schelling concludes, "is therefore beauty, and without beauty there is no work of art." ${ }^{19}$ Finally, "if beauty is essentially the resolution of an infinite conflict" ${ }^{20}$ experienced by artistic genius, it is in a work of art-at once finite and infinite - that man is at last reconciled with the world which had once opposed and even threatened to destroy him. Art is the mirror by which both the human and the inhuman recognize themselves in each other's beauty.

\section{The Kinship of Philosophy and Art}

After deducing the nature of the work of art, Schelling rather hastily ends the System of Transcendental Idealism with his reflections on the possible kinship of art and philosophy, and the affinity of the artist to the philosopher. According to him, what the transcendental philosopher is able to subjectively conceive in an intellectual intuition, the artist is able to produce objectively by way of his imagination: "aesthetic intuition simply is the intellectual intuition become objective." ${ }^{21}$ In other words, what for the transcendental philosopher is necessarily subjective and ideal — thus alienated and estranged from the objective world - is for the artist what could be objectively produced, made visible, and shown in reality. "The work of art," he says, "merely reflects to me what is otherwise not reflected by anything, namely the absolutely identical which has already divided itself even in the self." 22 What the philosopher stammers in articulating, the artist is able to eloquently depict in his art. Or, to paraphrase Wittgenstein, what otherwise cannot be said can nevertheless be shown. ${ }^{23}$

The kinship between philosophy and art can finally be stated as thus: transcendental philosophy is the absolute intellectually intuited and ideally expressed, while art is the absolute aesthetically intuited and beautifully illustrated. Philosophy and art are of kin in that philosophy provides the conditions of the possibility of art-namely, contradiction and opposition, dichotomy and distinction between the self and the world; while art for its part resolves and reconciles in beauty the differentiation and destruction all philosophizing

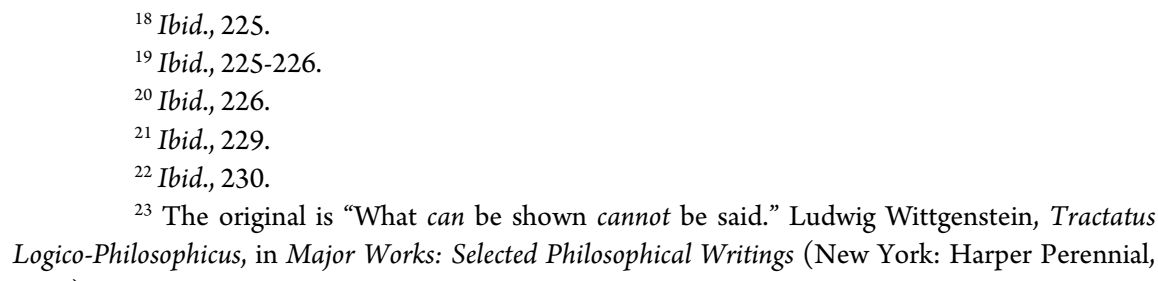

${ }^{23}$ The original is "What can be shown cannot be said." Ludwig Wittgenstein, Tractatus Logico-Philosophicus, in Major Works: Selected Philosophical Writings (New York: Harper Perennial, 2009), 4.1212, 29.

(c) 2012 Michael Stephen G. Aurelio http://www.kritike.org/journal/issue_11/aurelio_june2012.pdf ISSN 1908-7330 
necessarily leaves in its wake. ${ }^{24}$ Thus if one is to concede that art is philosophy made objective or seen, then "it is self-evident," Schelling says, "that art is at once the only true and eternal organ and document of philosophy, which ever again and continues to speak to us what philosophy cannot depict in external form." ${ }^{25}$ In the artist's ability to gather what the philosopher leaves shattered, Schelling concludes that

art is paramount to the philosopher, precisely because it opens to him, as it were, the holy of holies, where burns in eternal and original unity, as if in a single flame, that which in nature and history is rent asunder, and in life and action, no less than in thought, must forever fly apart. ${ }^{26}$

In what perhaps raised the eyebrows of other academic philosophers at that time, Schelling, who was called by some as the 'Prince of the Romantics', elevates the status of art to a rank as high as, or even higher, than that of philosophy itself. ${ }^{27}$ For if philosophy as Aristotle seems to say is the desire of man to become all things through knowledge, and if for his part Plato says that philosophy is the nostalgia of man to be reunited with what has been lost to himSchelling now declares that art, as the accomplishment of an absolute identity and unity between man and the world, is both the beginning and end of philosophy, its source and its hope. ${ }^{28}$ There lost in art is the original intimacy of being that philosophy after its inception and questioning can only wish to recover, and hidden by it is the magic stone by which the philosopher is able to transform all things back into himself.

The final aim of true philosophy is to return to the simple marvel and wonder of art, where all distinction before us disappears, and we once again or for the first

24 "Philosophy sets out from an infinite dichotomy of opposed activities; but the same dichotomy is also the basis of every aesthetic production, and by each individual manifestation of art it is wholly resolved." Schelling, System, 230.

${ }^{25}$ Ibid., 231.

${ }^{26} \mathrm{Ibid}$.

27 Because Schelling claims that "the true constitution of reality finds its ultimate manifestation in works of art," says Rolf-Peter Horstmann, "this view of the epistemic function of art was to become one of the cornerstones of late eighteenth- and early nineteenth-century romanticism." See Rolf-Peter Horstmann, "The Early Philosophy of Fichte and Schelling," in The Cambridge Companion to German Idealism, ed. by Karl Ameriks (Cambridge: Cambridge University Press, 2005), 134.

28 "Philosophy was born and nourished by poetry in the infancy of knowledge, and with it all those sciences it has guided toward perfection; we may thus expect them, on completion, to flow back like so many individual streams into the universal ocean of poetry from which they took their source." See Schelling, System, 232.

(c) 2012 Michael Stephen G. Aurelio http://www.kritike.org/journal/issue 11/aurelio june2012.pdf ISSN 1908-7330 
time become reunited with the absolute and the infinite-an experience which Schelling elsewhere said Plato had once likened to death. ${ }^{29}$

Department of Philosophy, Ateneo de Manila University, Philippines

\section{References}

Aristotle, De Anima, trans. by J. A. Smith, in Complete Works of Aristotle: The Revised Oxford Translation, ed. by Jonathan Barnes, vol. 1 (Princeton: Princeton University Press, 1995), 641-692.

Beiser, Frederick C., The Romantic Imperative: The Concept of Early German Romanticism (Cambridge: Cambridge University Press, 2003).

Frost, Robert, Selected Poems, with an introduction by Robert Graves (New York: Holt, Rinehart \& Winston, 1963).

Heidegger, Martin, Schelling's Treatise on the Essence of Human Freedom, trans. by Joan Stambaugh (Athens, Ohio: Ohio University Press, 1985).

Horstmann, Rolf-Peter, "The Early Philosophy of Fichte and Schelling," in The Cambridge Companion to German Idealism, ed. by Karl Ameriks, (Cambridge: Cambridge University Press, 2005), 117-140.

Kant, Immanuel, Critique of Judgment, trans by J.H. Bernard and with an introduction by Marc Luht (New York: Barnes \& Noble Books, 2005).

Schelling, F.W.J. System of Transcendental Idealism (1800), trans. by Peter Heather and with an introduction by Michael Vater (1978; Reprint, Charlottesville: University Press of Virginia, 2001).

Wittgenstein, Ludwig, Tractatus Logico-Philosophicus, in Major Works: Selected Philosophical Writings (New York: Harper Perennial, 2009).

29 " $\mathrm{He}$ who wishes to place himself in the beginning of a truly free philosophy must abandon even God. Here we say: [he] who wishes to maintain it, he will lose it; and [he] who gives it up, he will find it. Only he has come to the ground of himself and has known the whole depth of life who has once abandoned everything and has himself been abandoned by everything. He for whom everything disappeared and who saw himself alone with the infinite: a great step which Plato compared to death.” F.W.J. Schelling, quoted in Heidegger, Schelling's Treatise, 6.

(C) 2012 Michael Stephen G. Aurelio http://www.kritike.org/journal/issue_11/aurelio_june2012.pdf ISSN 1908-7330 